\title{
The Effect of the Perception of Learning Space at Home on the Learning Motivation of X.1 Grade Students Competency of Geomatic Engineering Expertise in the Vocational School of Vocational School, West Java Province
}

\author{
Nur Hanifah Ramadhani, Tjahyani Busono*, Nitih Indra Komala Dewi \\ Architectural Engineering Education Study Program, Department of Architectural Engineering Education \\ Faculty of Technology and Vocational Education \\ Universitas Pendidikan Indonesia \\ Bandung, Indonesia \\ *tjahyanibusono@upi.edu,nitih.dewi@upi.edu
}

\begin{abstract}
The learning environment in the classroom must meet several indicators so that students can be enthusiastic about learning. If it is related to the current pandemic condition, which causes learning to be carried out online from home, then ideally indicators to increase student enthusiasm for learning must be fulfilled in the home environment of each student, which is in line with several opinions by experts. This study aims to determine how the condition of the learning environment of students at home which focuses on the arrangement of the learning room, and also to determine the student's learning motivation and how the effect of the learning space at home on the learning motivation of each student. This research method is quantitative descriptive analytic. The research sample consisted of 32 students from class X.1. Geomatics Engineering SMK Negeri PU West Java. This research results that the perception of learning space at home has a positive or good value, with the sub-indicator of the highest score on the indicator of placing furniture or learning facilities that have been placed in a position that cannot hinder / interfere with learning activities. Meanwhile, the lowest subindicator is obtained in the indicator if in a closed room, there is an Air conditioner. While the results shown by the questionnaire to assess student learning motivation are in the high category, with the highest indicator on the qualification results indicator, namely feeling satisfied if the achievement results are better than before, and for the lowest indicators obtained on the indicators of desire to be praised by the closest person and desire. to be given an award (a gift in the form of material or money) if it gets a good value. The conclusion of this study shows that there is an influence on the perception of learning space at home on students' learning motivation, which is tested through a simple linear test, with a high category.
\end{abstract}

\section{INTRODUCTION}

Winataputra explains that the learning environment must pay attention to several things such as beauty, comfort, flexibility (flexibility), accessibility (easy to reach / easy to reach), and visibility (broadness of view) so that students can concentrate while learning and not being distracted by the physical environment of the study room. From the expert's opinion, it can be concluded that these aspects refer to spatial planning as a place of activity in this case, namely learning activities [1].

Aspects of the ideal learning environment according to the expert opinion above, are mostly formed to carry out formal learning activities of students in the school environment. However, referring to the policy of the Ministry of Education and Culture of the Republic of Indonesia in responding to the Covid-19 pandemic to enforce online learning from home for students, formal learning activities at schools are officially closed. To create an ideal learning environment for students, a learning environment at home should meet the principles of ideal study room arrangement. One of the goals to create an ideal learning environment is to increase the enthusiasm for learning or learning motivation of students. This is in line with the opinion of Dimyati that the learning environment factor of students is one of the other 6 (six) factors that can affect students' learning motivation [2].

Learning activities carried out online from home certainly have drawbacks, that is, each student has a different learning environment, so that the arrangement of the study room at

Keywords-home study layout, motivation to learn 
home is different for each student. One of these things can lead to differences in the learning motivation of each student.

Starting from the problems above, the author is interested in finding out more about the effect of the arrangement of learning spaces at home on student learning motivation.

\section{METHOD}

In this study, using descriptive research methods (analytical). Descriptive research belongs to research using a quantitative approach, so the method of calculation or formulation of the results of this study uses data that is calculated statistically.

This research was conducted by distributing questionnaires / questionnaires conducted online via Google Form which was carried out within a period of 2 (two) weeks.
In this study, the samples were students of class X.1 geomatics engineering competency at SMK PU Negeri West Java with the total number of students was 36 (thirty six) students.

\section{RESULTS AND DisCUSSION}

\section{A. Perceptions of Learning Spaces at Home}

In this study, variable $\mathrm{X}$ is the perception of students learning space at home in terms of six indicators represented by 14 item numbers, with each indicator having two / three question numbers on the questionnaire. For details on the results of the questionnaire for variable $X$ can be seen in the following table:

TABLE I. VARIABLE X QUESTIONNAIRE RESULTS

\begin{tabular}{|c|c|c|c|}
\hline No & Indicator & Sub indicators for assessment of learning space & $\begin{array}{l}\text { Total } \\
\text { Score }\end{array}$ \\
\hline \multirow[t]{2}{*}{1.} & \multirow[t]{2}{*}{ Room size } & $\begin{array}{l}\text { The size of the room is in accordance with the movements of students in the } \\
\text { room. }\end{array}$ & 33 \\
\hline & & - There are not many pieces of furniture that make the study space narrow & 36 \\
\hline \multirow[t]{2}{*}{2.} & \multirow{2}{*}{$\begin{array}{l}\text { Adequate number and condition of } \\
\text { furniture }\end{array}$} & - There are tables, chairs, lighting, writing instruments, books & 48 \\
\hline & & $\begin{array}{l}\text { - The furniture used (tables, chairs, lighting, stationery, books) is available in } \\
\text { good condition }\end{array}$ & 46 \\
\hline \multirow[t]{3}{*}{3.} & \multirow[t]{3}{*}{ Tidiness, cleanliness, health, humidity } & - Learning facilities are placed in a neat place & 32 \\
\hline & & - The study room is clean and does not smell bad & 43 \\
\hline & & - The study room is not damp & 50 \\
\hline \multirow[t]{2}{*}{4.} & \multirow[t]{2}{*}{ Lighting } & - There is natural lighting in the form of a window in the study room & 45 \\
\hline & & - Artificial lighting as needed in the form of room lights or study lights. & 43 \\
\hline \multirow[t]{3}{*}{5.} & \multirow[t]{3}{*}{ Adequate air circulation } & - The room temperature is neither too hot nor too cold & 45 \\
\hline & & - There are openings in the form of windows or air vents. & 41 \\
\hline & & - If in a closed room, there is Air conditioner & 24 \\
\hline \multirow[t]{2}{*}{6.} & \multirow[t]{2}{*}{ Accesibiility } & $\begin{array}{l}\text { - Learning facilities in the study room are placed in an easily accessible position } \\
\text { during learning activities }\end{array}$ & 43 \\
\hline & & $\begin{array}{l}\text { - Placement of furniture is placed in a position that cannot hinder / interfere with } \\
\text { learning activities }\end{array}$ & 53 \\
\hline
\end{tabular}

From the table above, it can be seen that the highest total score is obtained on the 6th indicator on the last problem No. (No.14), which is 53 points. This means that the sub-indicators of placing furniture or learning facilities that have been placed in a position that cannot obstruct / interfere with learning activities are the most fulfilled sub indicators in assessing perceptions of learning space at home by students. Meanwhile, the lowest sub-indicator is obtained in the 5th indicator in Problem 12, which is 24 points. This means that if the subindicator is in a closed room, there is air conditioner, it is the sub-indicator that is the least fulfilled in assessing the perception of learning space at home by students.

Based on the results of the assessment of variable $\mathrm{X}$ through a questionnaire / questionnaire, an overview can be taken of the calculation of the variable tendency test according to the weight of the assessment on the questionnaire. The results of the conclusion of the tendency of answers to question points on variable $\mathrm{X}$ can be seen in the following table:
TABLE II. GENERAL DESCRIPTION OF THE TENDENCY OF THE ANSWER TO VARIABLE $X$

\begin{tabular}{|l|l|l|}
\hline $\begin{array}{c}\text { Category } \\
\text { (according to the weight of } \\
\text { the assessment) }\end{array}$ & $\begin{array}{c}\text { Number of sample } \\
\text { answers }\end{array}$ & Percentage (\%) \\
\hline It is not in accordance with & 57 & 12,73 \\
\hline Quite appropriate & 96 & 21,42 \\
\hline Corresponding & 194 & 43,31 \\
\hline Very suitable & 101 & 22,54 \\
\hline Total: & 448 & 100 \\
\hline
\end{tabular}

From the table above, it can be concluded that the most number of sample answers (mode) is the assessment weight of 3 , namely the number of answers to the questionnaire by a sample of 194 or a percentage of $43.31 \%$, so it can be concluded that the learning space layout of all participants students at home are in good condition or positive values. 
it's getting no better

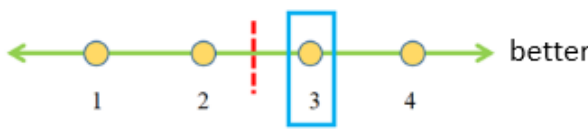

Fig. 1. The position of the conclusion of the students' perceptions score on the variable $\mathrm{x}$. Source: Research data

\section{B. Student's Motivation to Study}

The total score of the $\mathrm{Y}$ variable is obtained from the sum of the scores for each item of 17 question numbers regarding the learning motivation of students representing 8 question indicators with each indicator having two / three question numbers on the questionnaire. For details on the results of the $\mathrm{Y}$ variable questionnaire can be seen in the following table:

TABLE III. ACQUISITION OF TOTAL SCORE FOR EACH INDICATOR ON VARIABLE Y

\begin{tabular}{|c|c|c|c|}
\hline No & Indicator & Indicators of assessment of student learning motivation & $\begin{array}{r}\text { Total } \\
\text { Score } \\
\end{array}$ \\
\hline \multirow[t]{3}{*}{1.} & \multirow{3}{*}{$\begin{array}{l}\text { Diligent in facing tasks or be able to work } \\
\text { continuously; }\end{array}$} & - Attendance in online learning & 46 \\
\hline & & - Follow PBM on time & 43 \\
\hline & & - Repeating lessons & 41 \\
\hline \multirow[t]{2}{*}{2.} & \multirow{2}{*}{$\begin{array}{l}\text { Resilient in facing difficulties and not easily } \\
\text { discouraged, not easily satisfied with the } \\
\text { achievements obtained; }\end{array}$} & - Attitude to adversity & 54 \\
\hline & & - Attempts to overcome difficulties & 43 \\
\hline \multirow[t]{2}{*}{3.} & \multirow{2}{*}{$\begin{array}{l}\text { Shows great interest in a variety of learning } \\
\text { problems; }\end{array}$} & - Habits in following lessons & 52 \\
\hline & & - Spirit in participating in PBM & 45 \\
\hline \multirow[t]{2}{*}{4.} & \multirow[t]{2}{*}{ Excellent in learning; } & - The desire to excel & 56 \\
\hline & & - Qualification of results & 57 \\
\hline \multirow[t]{2}{*}{5.} & \multirow{2}{*}{$\begin{array}{l}\text { Enjoys finding and solving problems alone or in } \\
\text { groups; }\end{array}$} & - Completion of assignments / homework & 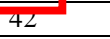 \\
\hline & & - Doing assignments / homework in free time & 40 \\
\hline \multirow[t]{2}{*}{6.} & \multirow[t]{2}{*}{ There are hopes and dreams for the future; } & - There is a desire to enter your favorite college & 54 \\
\hline & & - There is a desire to work for a company that requires good grades. & 55 \\
\hline \multirow[t]{2}{*}{7.} & \multirow[t]{2}{*}{ There is an appreciation in learning. } & $\begin{array}{l}\text { - The desire to be praised by the closest people (parents, siblings, teachers, } \\
\text { lovers) if they get good learning results. }\end{array}$ & 39 \\
\hline & & $\begin{array}{l}\text { - The desire to be given an award (a gift in the form of material or money) if it } \\
\text { gets a good score. }\end{array}$ & 39 \\
\hline \multirow[t]{2}{*}{8.} & \multirow[t]{2}{*}{ The existence of a conducive learning environment } & - A safe, orderly and beautiful environment, the more enthusiasm for learning. & 54 \\
\hline & & $\begin{array}{l}\text { - A safe, orderly and beautiful environment will make you more motivated to } \\
\text { learn. }\end{array}$ & 55 \\
\hline
\end{tabular}

From the table above, it can be seen that the highest total score is obtained on the 4th indicator on Problem 9, which is 57 points. This means that the result qualification subindicator, that is, is satisfied if the achievement results are better than before, is the most fulfilled sub indicator in assessing learning motivation by students. Meanwhile, the lowest sub-indicator was obtained in the 7 th indicator in Problem No. 14 and No.15, namely 39 points. This means that the sub-indicator is the desire to be praised by the closest person and the desire to be given an award (a gift in the form of material or money) if it gets a good value., is the sub-indicator that is least met in the assessment of students' perceptions of home learning layouts.

As with the treatment of variable $\mathrm{X}$, to obtain a general picture of students' learning motivation, the research sample is calculating the tendency to answer. The assessment points on the questionnaire include the assessment criteria ranging from Strongly disagree with the weight of the assessment $=1$, to the criterion Strongly agree with the weight of the assessment $=$ 4.The results of the conclusions on the answer to the research sample of variable $\mathrm{Y}$ can be seen in the following table:
TABLE IV. GENERAL DESCRIPTION OF THE TENDENCY OF THE ANSWER TO VARIABLE Y

\begin{tabular}{|l|l|l|}
\hline \multicolumn{1}{|c|}{ Category } & \multicolumn{1}{c|}{$\begin{array}{c}\text { Number of sample } \\
\text { answers }\end{array}$} & Percentage (\%) \\
\hline Low & 15 & 2,76 \\
\hline High enough & 66 & 12,13 \\
\hline High & 271 & 49,82 \\
\hline Very high & 192 & 35,29 \\
\hline Total: & 544 & 100 \\
\hline
\end{tabular}

From the table above, it can be concluded that the most number of sample answers (mode) is the score of 3 with the agreed answer criteria, namely the number of answers to the questionnaire by the sample is 271 or with a percentage of $49.82 \%$. So it can be concluded that the learning layout of all students at home is in good condition or has positive values.

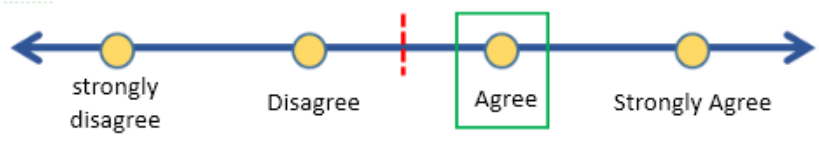

Fig. 2. The position of the conclusion of the students' perceptions score on the variable $y$. 


\section{The Influence of Perceptions of Learning Space at Home on Learning Motivation}

From the total score of each item on the variable y (learning motivation), it shows that one of the serial number 26 students has the highest score, which is 64 points. From the total score of students' learning motivation, the condition of these students' learning spaces can be used as a reference in describing the visualization of good spatial planning that can increase students' learning motivation. For the results of visualizing the conditions of the learners' learning space can be seen in the image below:

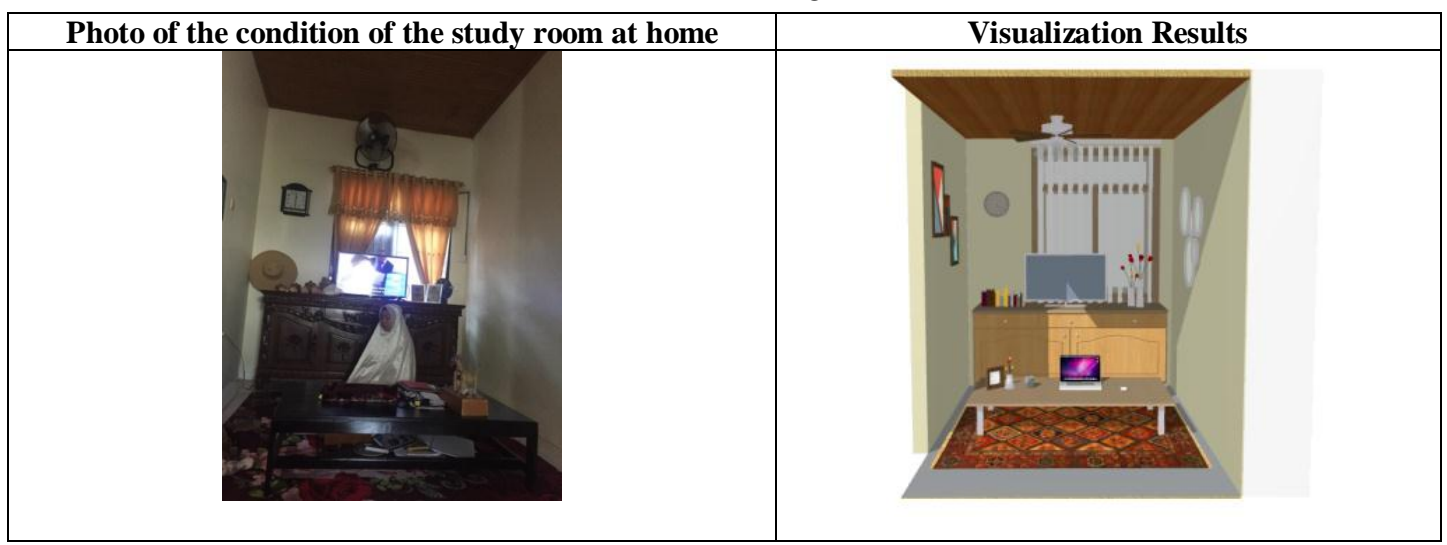

Fig. 3. The layout of the learners' learning space with the highest learning motivation score.

TABLE V. ACQUISITION OF SCORES FOR EACH ITEM ON VARIABLE X BY STUDENT NO.26

\begin{tabular}{|c|c|c|c|c|c|c|c|c|c|c|c|c|c|c|c|c|}
\hline No. & Student Name & $\mathbf{1}$ & $\mathbf{2}$ & $\mathbf{3}$ & $\mathbf{4}$ & $\mathbf{5}$ & $\mathbf{6}$ & $\mathbf{7}$ & $\mathbf{8}$ & $\mathbf{9}$ & $\mathbf{1 0}$ & $\mathbf{1 1}$ & $\mathbf{1 2}$ & $\mathbf{1 3}$ & $\mathbf{1 4}$ & Total \\
\hline 26 & NA & 4 & 4 & 3 & 3 & 4 & 3 & 3 & 2 & 2 & 3 & 3 & 3 & 3 & 3 & 43 \\
\hline
\end{tabular}

Visualization of students' perceptions of learning space with a total score of variable $\mathrm{Y}$ (motivation to learn at home) is obtained from the scores inputted by these students on each item of variable $\mathrm{X}$ (perception of learning space at home) which can be seen in Table 4.25 and also through photos the actual situation in the student's learning room with serial number 26. From the data inputted by these students, it can be seen that the average answer regarding the conditions of the study room at home shows a value that is close to the very good category (according to the description of the perception of the assessment), namely from a total of 14 question items with variable $X, 9$ items with a value 3 points, and 3 question items with a value of 4 points. While the rest get 2 points, namely on the lighting indicator, where the study room at home gets artificial light in the form of room lights that are considered dim.

Meanwhile, the total score that occupies the lowest position in the y variable (learning motivation) is indicated by one of the serial number 19 students with a total of 41 points. From the total score of students' learning motivation, the condition of the students' learning space can be used as a reference in describing the visualization of spatial planning that has not been good which can affect students' learning motivation. The results of visualizing the conditions of the learning space of these students can be seen in the picture below. this:

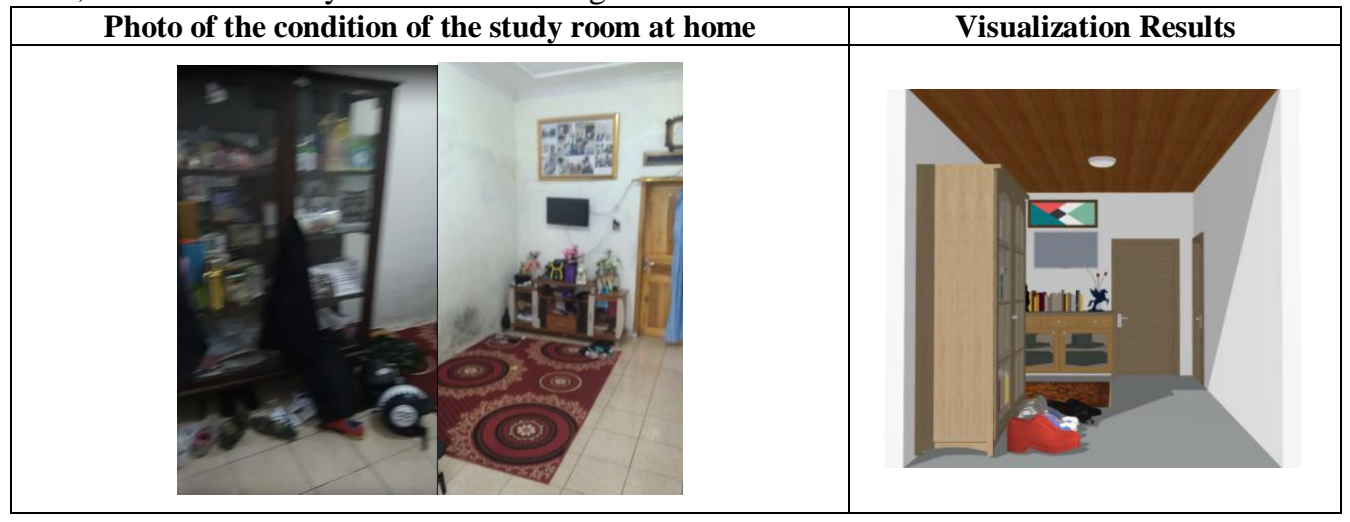

Fig. 4. The layout of the students' learning space with the lowest learning motivation score. 
TABLE VI. ACQUISITION OF SCORES FOR EACH ITEM ON THE VARIABLE X BY STUDENTS No.19

\begin{tabular}{|c|c|c|c|c|c|c|c|c|c|c|c|c|c|c|c|c|}
\hline $\begin{array}{c}\text { No } \\
\text {. }\end{array}$ & Student Name & $\mathbf{1}$ & $\mathbf{2}$ & $\mathbf{3}$ & $\mathbf{4}$ & $\mathbf{5}$ & $\mathbf{6}$ & $\mathbf{7}$ & $\mathbf{8}$ & $\mathbf{9}$ & $\mathbf{1 0}$ & $\mathbf{1 1}$ & $\mathbf{1 2}$ & $\mathbf{1 3}$ & $\mathbf{1 4}$ & Total \\
\hline 19 & $\mathrm{MF}$ & 3 & 2 & 3 & 3 & 2 & 2 & 2 & 1 & 3 & 3 & 2 & 1 & 2 & 4 & 33 \\
\hline
\end{tabular}

Through the data inputted by the student serial number 19 , it can be seen that the average answer to the conditions of the study room at home shows a varying value, namely from a total of 14 question items with variable X, 1 item with a value of 4 points, 5 items. questions with a value of 3 points, 6 item questions with a value of 2 points and 2 item questions with a value of 1 point. This shows that the average condition of the study room at home by these students is at a sufficient level (according to the perception of the assessment), meaning that many aspects of supporting learning activities at home by these students must be further improved so that these students can be more motivated. to learn.

Apart from the influence between the variables above, as has been shown by the visualization of the perceptions of students 'learning layouts with the highest and lowest learning motivation scores, the essence of this study results that the effect of perceptions of home study layouts on students' learning motivation can be seen. From the results of the calculation of the linear regression coefficient which is then calculated using hypothesis testing, besides that the magnitude of this influence can be seen from the calculation of the coefficient of determination.

The results of the calculation of the linear regression coefficient in this study produce an equation in the form of $\mathrm{Y}=$ $4,913+1,256 \mathrm{X}$. From this equation it can produce a graph output forming a pattern from bottom left up to top right which indicates that there is a linear and positive influence between the perception of learning space variables in house (x) and students' learning motivation (y). The positive effect in this graph means that if the students' learning layout has increased, the students' learning motivation will also increase.

From the linear test equation, the next data test step was carried out, namely the hypothesis test which resulted in t value (15.096)> t table (2.042), so that it can be concluded that Ho is rejected and $\mathrm{Ha}$ is accepted, which means "there is a significant influence between spatial perceptions. study at home with students' learning motivation "To determine the value of the presentation of the effect of variable $\mathrm{X}$ on variable $\mathrm{Y}$, a determination test was used which showed that the home study layout had an effect of $87 \%$ on the learning motivation of students.

Based on some of the above, it can be concluded that the hypothesis proposed in this study (Ha) is accepted.

\section{CONCLUSION}

From the results of research and data analysis that has been carried out by researchers regarding the effect of perceptions of home learning layouts on students' learning motivation, several conclusions can be drawn, namely:
- Perceptions of home study layout that have been researched on students of Class X.1 Geomatics Engineering of State Vocational School of Public Works, West Java, have a positive or good value, which means that the spatial arrangement by students in this study mostly has met the theory or structuring criteria good room, which is reviewed through several indicators of perceptions of home learning layout by collecting student perception assessment points through a questionnaire. Through several indicators that are used as a measuring tool in assessing perceptions of learning space at home, it results in the highest score obtained on the indicators of placing furniture or learning facilities that have been placed in a position that cannot hinder / interfere with learning activities. Whereas for the lowest sub-indicator, namely the indicator if in a closed room, there is Air conditioner, which is the most unfulfilled sub indicator in assessing the perception of learning space at home by students.

- Student learning motivation in terms of external and internal influences through several indicators by several expert theories, shows that the level of student motivation used in the sample of this study shows a positive value in terms of the number of points that get the most responses from the sample is at point 3 with a weight of 3 points. Thus, the level of learning motivation for students in Class X.1 Geomatics Engineering, State Vocational School of Public Works, West Java is at a good percentage, namely $49.82 \%$. Through several indicators that are used as a measuring tool in assessing the learning motivation of students, it results in the highest score obtained on the 4th indicator on Problem 9, which is 57 points. This means that the results qualification sub-indicator, namely feeling satisfied if the achievement results are better than before, is the most fulfilled sub indicator in the assessment of learning motivation by students. Meanwhile, the lowest sub-indicator was obtained in the 7th indicator in Problem No. 14 and No.15, namely 39 points. This means that the sub-indicator is the desire to be praised by the closest person and the desire to be given an award (a gift in the form of material or money) if it gets a good value. , is the sub-indicator that is least met in the assessment of students' perceptions of home learning layouts.

- The effect of the perception of learning space at home on the learning motivation of students as assessed through a simple linear regression test shows that the better the arrangement of the study room at home will result in the higher the learning motivation of students, so that after proceeding through hypothesis testing, it 
gives results In the form of $\mathrm{Ho}$ rejected and $\mathrm{Ha}$ accepted, which means "there is a significant effect of the perception of learning space at home on the learning motivation of students" as much as $87 \%$ which was tested through the test of determination.

\section{REFERENCES}

[1] U. Winataputra, Buku Materi Pokok Strategi Belajar Mengajar. Jakarta: Depdikbud, 1998.

[2] M. Dimyati, Belajar dan Pembelajaran. Jakarta : PT.Rineka Cipta, 2006. 